\title{
Mirosław SKARŻYŃSKI
}

Poznań

\section{Wpływ kryzysu gospodarczego na bezpieczeństwo zdrowia publicznego w UE}

\section{Wstęp}

$\mathbf{Z}$ drowie jest zasadniczą wartością w życiu każdego człowieka, a uprawnienie do zdrowia należy do katalogu praw podstawowych. Realizacja tego zasadnego roszczenia w wymiarze gwarantującym bezpieczeństwo zdrowia musi być wspierana skuteczną polityką państwa ${ }^{1}$.

Ochrona zdrowia oznacza całokształt zorganizowanych działań, podejmowanych z wykorzystaniem odpowiednich urządzeń, norm prawnych i instytucji na rzecz szeroko rozumianego zdrowia społeczeństwa. W państwach UE, środki na finansowanie ochrony zdrowia czerpie się z różnych źródeł, wykorzystywanych w zmiennych proporcjach, tj. funduszy publicznych i funduszy prywatnych. Źródła publiczne to głównie budżety państwa, budżety regionów i budżety lokalne oraz fundusze ubezpieczeń publicznych i fundusze parabudżetowe, zaś źródła prywatne to przede wszystkim budżety gospodarstw domowych, prywatne ubezpieczenia zdrowotne oraz fundusze korporacji. Tradycyjnie znaczącą rolę odgrywa dobroczynność. Fundusze pochodzące z działalności filantropijnej, przyjęto rozpatrywać na równi z funduszami publicznymi wówczas, gdy są dotowane z funduszy publicznych, bądź na równi z funduszami prywatnymi, jeśli nie są dotowane z funduszy publicznych.

Dostępność opieki zdrowotnej, wykorzystującej najnowsze osiagnnięcia nauk biomedycznych, a tym samym zapewniającej poprawę jakości i komfortu życia, a zarazem w licznych stanach zagrożenia, chroniącej przed przedwczesną śmiercią - gwarantuje społeczeństwu wartość wręcz niewymierną, jaką jest poczucie bezpieczeństwa zdrowia. Podkreślić należy, iż poczucie bezpieczeństwa zdrowia w coraz większym stopniu zależy nie tyle od stopnia dostępności ogółu świadczeń zdrowotnych, ile od możliwości uzyskania wysoko specjalistycznej, opartej na najnowszych zdobyczach technologii opieki medycznej oraz od jakości usług medycznych ${ }^{2}$.

Narastające potrzeby i koszty świadczeń zdrowotnych wymagają zwiększania środków finansowych przeznaczonych na funkcjonowanie systemów ochrony zdrowia ${ }^{3}$. W warunkach kryzysu gospodarczego, zapewnienie akceptowalnego przez obywateli poziomu bezpieczeństwa zdrowia staje się więc coraz bardziej problematyczne, z powodu coraz niższych dochodów budżetu państwa i narastających wydatków publicznych.

\footnotetext{
${ }^{1}$ Stanowisko Rzqdowej Rady Ludnościowej w sprawie „Bezpieczeństwo zdrowotne ludności Polski”, http://www.stat.gov.pl/cps/rde/xbcr/bip/BIP_stanowisko_RRL_bezp_zdrow_ludnosci.pdf, 15.01.2012.

2 Podstawy zarzqdzania zakładem opieki zdrowotnej, red. M. Dobska, K. Rogoziński, Warszawa 2008, s. 67, 70,82

${ }^{3}$ K. Kissimova-Skarbek, Finansowanie opieki zdrowotnej, w: Zdrowie publiczne. Wybrane zagadnienia, t. II, red. A. Czupryna, S. Poździoch, A. Ryś, W. C. Włodarczyk, Kraków 2001, s. 11.
} 


\section{Podstawy bezpieczeństwa zdrowia}

W Europie nawet najbogatsze kraje zmagają się z problemem jak najlepszego dostosowania swoich systemów ochrony zdrowia do przeciwdziałania tzw. starym wyzwaniom zdrowotnym np. HIV/AIDS, gruźlica, a także powracającym chorobom, takim jak SARS i ptasia grypa, jak również klęskom humanitarnym, zagrożeniom zdrowia wynikającym ze zmian klimatycznych lub degradacji środowiska naturalnego oraz rozwoju międzynarodowych podróży i globalnego handlu.

Europejscy eksperci Światowej Organizacji Zdrowia (WHO) wskazują system ochrony zdrowia jako kluczowy element utrzymywania kontroli nad negatywnym wpływem zjawisk - katastrof rodzących negatywne skutki zdrowotne i kryzysów prowadzących do obniżenia poziomu bezpieczeństwa zdrowia.

Podniesienie stanu bezpieczeństwa zdrowia jest uzależnione przede wszystkim od kondycji systemu ochrony zdrowia. Niedofinansowany i źle zarządzany, a więc słaby i nieprzygotowany system ochrony zdrowia stanowi krytyczne ogniwo w łańcuchu reakcji na zagrożenia zdrowotne, utrudniające prowadzenie skutecznych działań w sytuacjach nagłych. Odwrotnie - zasobny i dobrze zarządzany, tym samym silny i właściwie przygotowany system ochrony zdrowia jest w stanie skutecznie powstrzymać wystąpienie zdarzenia zapoczątkowującego problemy zdrowotne, przed przekształceniem się ich w kryzys bezpieczeństwa ${ }^{4}$.

Zatem zagrożenia bezpieczeństwa zdrowia są liczne i zróżnicowane. Przeciwstawianie się skutkom zdrowotnym ich oddziaływania wymaga nierzadko wspólnych wysiłków dla poprawy stopnia przygotowania i skutecznego reagowania na różnego rodzaju zjawiska. Złożony charakter współczesnych zagrożeń bezpieczeństwa zdrowia oraz wymaganych sytuacją działań podejmowanych w celu ochrony populacji powodują, że problemy te dotyczą nie tylko rządów, ale również organizacji międzynarodowych, społeczeństw obywatelskich i biznesu. Współpraca na wielu poziomach jest, więc nieodzowna, jednak każdy kraj sam musi inwestować w zdrowie społeczeństwa i tworzyć własny potencjał zdolny do zapobiegania teraźniejszym i przyszłym zagrożeniom przez wzmocnienie narodowego systemu ochrony zdrowia. Wiąże się to często z koniecznością zwiększenia nakładów, szczególnie na monitorowanie i zapobieganie zagrożeniom chorobowym oraz edukację ${ }^{5}$.

Bezpieczeństwo zdrowia stało się strategicznym priorytetem UE z powodu nasilania się m.in. takich czynników determinujących stan zdrowia, jak:

- przeobrażenia demograficzne, w tym starzenie się społeczeństw, co wpływa na zmianę struktury chorób, znacząco podnosi koszty i zagraża równowadze unijnych systemów ochrony zdrowia;

— zmiany warunków środowiskowych, w tym związanych z klimatem, poszerzającą się sferą nierówności społecznych i przemieszczaniem się całych grup ludności, co sprzyja występowaniu katastrof naturalnych o szerokim, nawet regionalnym czy globalnym zasięgu oraz zwiększa zagrożenie epidemiczne i bioterroryzmem;

— rozwój nowych technologii, które rewolucjonizują sposoby, w jaki promuje się zdrowie, zapobiega zagrożeniom zdrowotnym i leczy choroby.

\footnotetext{
${ }^{4}$ Światowy Dzień Zdrowia 2007, http://kobieta.wp.pl/kat,26377,title,Swiatowy-Dzien-Zdrowia-2007,wid,8810278, wiadomosc.html?ticaid=1e46d, 15.04.2012; Światowy Dzień Zdrowia 2007, Uniwersyteckie Centrum Kliniczne, https://www.uck.gda.pl/content/view/983/90/, 14.04.2012.

${ }^{5}$ Przesłanie Dyrektora Generalnego, http://pck.org.pl/images/news_obraz/2007_sdz/Przeslanie_DG_WHO.pdf, 15.04.2012.
} 
W obliczu tych zagrożeń, Komisja Wspólnoty Europejskiej przyjęła na lata 2008-2013, trzy cele strategiczne:

1) propagowanie zdrowia w starzejącej się Europie;

2) ochrona obywateli przed zagrożeniami dla zdrowia;

3) monitorowanie funkcjonowania systemów ochrony zdrowia i nowych technologii.

Istotą strategii UE w dziedzinie bezpieczeństwa zdrowia jest równość obywateli w dostępie do opieki zdrowotnej, tak by każda osoba, bez względu na wiek, płeć, zamieszkanie i zamożność, w razie poczucia zagrożenia zdrowia, mogła skorzystać z odpowiednich świadczeń zdrowotnych ${ }^{6}$.

\section{Wspólczesny kryzys gospodarczy}

Kryzysy gospodarcze, czyli okresowe zwolnienia aktywności gospodarczej, są zjawiskami znanymi od wieków. W przeszłości o ich częstotliwości decydowały przede wszystkim czynniki zewnętrzne w stosunku do gospodarki, tj. zjawiska naturalne (klęski żywiołowe, epidemie, nieurodzaje) lub przyczyny polityczne (wojny). Słabość rynków wewnętrznych i ograniczone możliwości transportu na ogół nie pozwalały na efektywne zwiększenie podaży żywności i przeciwdziałanie klęskom głodu. Wraz z rozwojem gospodarki rynkowej na przebieg koniunktury w coraz mniejszym stopniu wpływały zjawiska naturalne, a w coraz większym - czynniki ekonomiczne. Pojawiły się kryzysy nadprodukcji, polegające na tym, że podaż przewyższała popyt, więc wytworzonych dóbr nie można było sprzedać, a ich ceny spadały.

W XVII i XVIII w., po okresach spekulacji w Europie nastąpiły pierwsze duże kryzysy finansowe. W XIX w., wraz z uprzemysłowieniem, ukształtował się mechanizm 4-fazowego 6-12-letniego cyklu koniunkturalnego, obejmującego nie tylko finanse, ale również poszczególne gałęzie produkcji. Kryzysy nadprodukcji, najwcześniej pojawiły się w Wielkiej Brytanii. Pod koniec XIX w., pod wpływem monopolizacji, charakter kryzysów zaczął się zmieniać.

W XX w., cykl koniunkturalny nie był już tak regularny, a w latach 1929-1936 świat dotknął Wielki Kryzys. Po II wojnie światowej pojawiły się zjawiska nowego typu - kryzysy naftowe, którym towarzyszyła inflacja, gdy dotychczasowe kryzysy działały deflacyjnie. Po 1989 r. doszło do załamania koniunktury w rezultacie kresu zimnej wojny i redukcji wydatków zbrojeniowych. Do lat dziewięćdziesiątych, peryferyjne kryzysy finansowe nie przenosiły się na gospodarkę amerykańską, która utrzymywała dobrą koniunkturę i ciągnęła za sobą resztę świata. Jednak w latach 2000-2001 doszło do pogorszenia koniunktury w Stanach Zjednoczonych, a jej skutki zaczął odczuwać cały świat".

W pierwszej dekadzie XXI w. wybuchł globalny kryzys finansowy. Jego przyczyny są dużo bardziej złożone, niż w przypadku innych kryzysów finansowych, w tym także najpoważniejszego w skutkach kryzysu finansowego lat 30-tych XX w. Czynnikiem inicjującym ostatni kryzys, zwanym w wielu teoriach ekonomicznych „szokiem”, był dynamiczny rozwój amerykańskiego rynku nieruchomości, który doprowadził do intensywnego wzrostu cen domów w stosunkowo krótkim czasie. Pęknięcie „,bańki” na rynku nieruchomości w Stanach

\footnotetext{
${ }^{6}$ Stanowisko Rzqdowej Rady Ludnościowej..., op. cit.

${ }^{7}$ W. Morawski, Kronika kryzysów gospodarczych, Warszawa 2003, s. 9-13; J. Szpak, Historia gospodarcza powszechna, Warszawa 2007, s. 298-299.
} 
Zjednoczonych przyczyniło się do wybuchu kryzysu finansowego wzmagającego turbulencje najpierw w sektorze finansowym.

W konsekwencji zawirowań na rynkach finansowych, ucierpiały również gospodarki wielu krajów. W pierwszej kolejności, poprzez kanały oddziaływania na możliwości konsumpcyjne gospodarstw domowych oraz nastroje konsumentów, kryzys finansowy spowodował spadek konsumpcji, która w większości krajów wysoko rozwiniętych stanowi główny komponent produktu krajowego brutto. Z kolei znaczący wzrost kosztu pozyskania kapitału będący konsekwencją załamania się rynków papierów wartościowych oraz rynku tradycyjnego kredytu w połączeniu z uszczupleniem wydatków konsumpcyjnych oraz wzrostem awersji do ryzyka spowodował zmiany w podejściu przedsiębiorstw do inwestycji, odgrywających istotną rolę w tworzeniu produktu krajowego brutto. W końcu, osłabienie międzynarodowej aktywności handlowej wpłynęło negatywnie w szczególności na gospodarki nadmiernie uzależnione od eksportu, w istotnym stopniu kontrybuującego do ich produktu krajowego brutto. W rezultacie ograniczenia aktywności gospodarczej po wybuchu globalnego kryzysu finansowego, wiele krajów, w tym m.in. Irlandia, Niemcy, Japonia, Szwecja, Włochy, oficjalnie wkroczyło w fazę recesji. W celu zniwelowania negatywnego wpływu kryzysu finansowego na gospodarkę, rządy licznych krajów ogłosiły programy stymulujące wzrost gospodarczy obliczone na setki miliardów USD.

Obecnie jest jeszcze zbyt wcześnie, by w pełni odczuć efekty wprowadzenia w życie przez rządy wielu krajów rozmaitych planów ratunkowych dla sektora finansowego oraz programów wspierania gospodarki, przewidzianych na długie lata. Jednak odbudowanie zaufania na rynkach finansowych, tak bardzo zachwianego wydarzeniami kryzysowymi wymaga czasu oraz konkretnych rozwiązań regulacyjnych na nowo wyznaczających granice ryzyka podejmowanego przez banki i jednocześnie czyniących rynki finansowe bardziej transparentnymi ${ }^{8}$.

\section{Kryzys gospodarczy a bezpieczeństwo zdrowia}

Bezpieczeństwo zdrowia jest ściśle związane z sytuacją gospodarczą danego państwa, a zarazem całej UE. Rodząca obawy zła kondycja gospodarki (w tym także zahamowanie wzrostu gospodarczego) jest ważnym przyczynkiem do pogorszenia stanu zdrowia obywateli będącego jednocześnie czynnikiem zmniejszającym szanse rozwoju danego kraju i całej UE ${ }^{9}$.

Niekorzystna sytuacja gospodarcza prowadzi do zmniejszenia produktu krajowego brutto i dochodu narodowego, determinując zarówno poziom zdrowia jednostek, jak i społeczeństwa oraz gotowość systemu opieki zdrowotnej do realizacji zadań w sytuacjach nagłych. Jednocześnie przyczynia się do obniżenia przeciętnego poziomu życia oraz zmiany modelu konsumpcji będącej następstwem dysponowania przez ludzi niższymi dochodami i mniejszą ilością wolnego czasu. Wynikające z obniżenia ogólnego poziomu dobrobytu coraz gorsze warunki egzystencji (w tym żywieniowe i higieniczne) bezpośrednio wpływają na osłabienie odporności organizmu ludzkiego, a więc przyczyniają się do nasilenia występowania stanów chorobowych, nierzadko o wydłużonym czasie trwania. Ponadto obniżone dochody pozwalają w mniejszym wymiarze przeznaczać środki na ubezpieczenia zdrowotne i finansowanie

\footnotetext{
${ }^{8}$ W. Nawrot, Globalny kryzys finansowy XXI wieku. Przyczyny, przebieg, skutki, prognozy, Warszawa 2009, S. $159,162$.

${ }^{9}$ C. Włodarczyk, S. Poździoch, Pojęcie i zakres zdrowia publicznego, w: Zdrowie publiczne. Wybrane zagadnienia, t. I, red. A. Czupryna, S. Poździoch, A. Ryś, W. C. Włodarczyk, Kraków 2000, s. 18-19.
} 
ochrony zdrowia $^{10}$. Wpływa to bezpośrednio na obniżenie skuteczności stosowanych procedur medycznych i z reguły utrudnia do nich powszechny dostęp. Występuje, więc wydłużenie procesu powrotu do pełnego zdrowia, co jest niekorzystne zarówno dla obywatela, jak i całej populacji (rysunek 1).

Wynika z tego, że procesy kryzysowe w gospodarce, które oznaczają spadek produktu krajowego brutto i dochodu narodowego w poszczególnych państwach UE, przekładają się na pogorszenie sytuacji gospodarczej określonego kraju, jak i gospodarstw domowych, co może uniemożliwiać zwiększenie, a nawet prowadzić do zmniejszenia wydatków publicznych i prywatnych na opiekę zdrowotną, a tym samym być źródłem obniżenia poziomu bezpieczeństwa zdrowia indywidualnego, lokalnego, narodowego, regionalnego i jednocześnie globalnego.

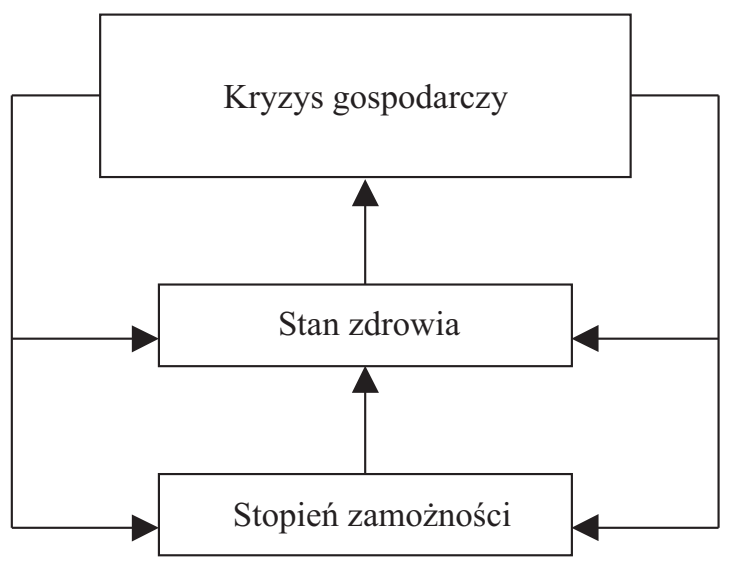

Rys. 1. Stan zdrowia populacji w sytuacji kryzysu gospodarczego

Źródlo: Opracowanie własne.

\section{Cel badań}

Celem przeprowadzonego badania było ustalenie, analiza i ocena wpływu kryzysu gospodarczego na bezpieczeństwo zdrowia publicznego w UE.

\section{Materialy}

W badaniach wykorzystano dane statystyczne charakteryzujące sytuację makroekonomiczną oraz finansowanie ochrony zdrowia $\mathrm{w}$ badanych państwach $\mathrm{z}$ pięciu lat, $\mathrm{w}$ tym $\mathrm{z}$ trzech ostatnich, dotychczas opublikowanych.

\section{Metoda}

W postępowaniu analitycznym wykorzystano następujące miary:

— produkt krajowy brutto,

${ }^{10}$ P. Białynicki, Wpływ zdrowia na ksztaltowanie się spotecznego dobrobytu, „Biuletyn Ekonomiczny GAP” 2007, nr 3, http://www.biuletyn.e-gap.pl/index.php?view=artykul\&artykul=43, 27.03.2012. 
— produkt krajowy brutto przypadający na jednego mieszkańca,

- wydatki na ochronę zdrowia ogółem w procentach produktu krajowego brutto,

— wydatki na ochronę zdrowia ogółem w przeliczeniu na jednego mieszkańca.

\section{Zakres przestrzenny badań}

Badaniami objęto 19 z 27 państw członkowskich UE, tj. takie jak: Austria, Belgia, Czechy, Dania, Estonia, Finlandia, Francja, Hiszpania, Holandia, Irlandia, Luksemburg, Niemcy, Polska, Słowacja, Słowenia, Szwecja, Węgry, Wielka Brytania, Włochy. Z powodu braku lub niekompletności danych w badaniach nie ujęto 8 państw, do których należały: Bułgaria, Cypr, Grecja, Litwa, Łotwa, Malta, Portugalia i Rumunia.

\section{Zakres czasowy badań}

Dolną granicę przedziału badań wyznacza 2000 r., zaś górną - 2009 r. Oprócz tych dwóch lat, badaniami objęto dane z 2005, 2007 i 2008 r.

\section{Wyniki i ich omówienie}

W latach 2000-2009 wystapił zdecydowany wzrost produktu krajowego brutto we wszystkich rozpatrywanych państwach UE. Wynika z tego, że następowało stopniowe, choć nieregularne, zwiększanie się wartości produkcji wytworzonej w gospodarce każdego kraju $\mathrm{w}$ ciagu kolejnych lat. Jednak dynamika przyrostu produktu krajowego brutto w latach 2000-2005 była zdecydowanie wyższa niż w latach 2005-2009 (tabela 1).

Tabela 1

Produkt krajowy brutto w państwach UE w latach 2000-2009

\begin{tabular}{||c|c|c|c|c|c||}
\hline \multirow{3}{*}{ Państwo } & \multicolumn{5}{|c||}{ lata } \\
\cline { 2 - 6 } & \multicolumn{5}{|c|}{ PKB (ceny bieżące) wg kursów walut } \\
\cline { 2 - 6 } & $\mathbf{2 0 0 0}$ & $\mathbf{2 0 0 5}$ & $\mathbf{2 0 0 7}$ & $\mathbf{2 0 0 8}$ & 2009 \\
\cline { 2 - 6 } & mId USD & mId USD & mld USD & mId USD & mId USD \\
\hline Austria & 2 & 3 & 4 & 5 & 6 \\
\hline Belgia & 191,2 & 304,8 & 370,7 & 412,9 & 381,1 \\
\hline Czechy & 231,9 & 370,8 & 458,4 & 504,9 & 471,2 \\
\hline Dania & 56,7 & 124,0 & 174,0 & 216,1 & 190,2 \\
\hline Estonia & 160,1 & 259,1 & 310,1 & 340,8 & 308,9 \\
\hline Finlandia & 5,6 & 12,8 & 21,3 & 23,5 & 19,3 \\
\hline Francja & 121,9 & 195,7 & 246,0 & 269,8 & 237,8 \\
\hline Hiszpania & 1328,0 & 2126,6 & 2589,8 & 2856,5 & 2649,4 \\
\hline Holandia & 580,7 & 1126,0 & 1437,9 & 1594,5 & 1464,1 \\
\hline Irlandia & 385,1 & 628,8 & 776,1 & 872,9 & 794,6 \\
\hline Luksemburg & 96,6 & 200,4 & 260,9 & 266,3 & 221,8 \\
\hline Niemcy & 20,3 & 36,6 & 49,7 & 57,6 & 52,9 \\
\hline Polska & 1900,2 & 2786,9 & 3316,1 & 3655,9 & 3330,0 \\
\hline \hline
\end{tabular}




\begin{tabular}{||l|c|c|c|c|c||}
\hline \multicolumn{1}{|c|}{1} & 2 & 3 & 4 & 5 & 6 \\
\hline Słowacja & 20,4 & 47,4 & 75,0 & 94,8 & 87,6 \\
\hline Słowenia & 19,6 & 34,0 & 45,9 & 54,4 & 49,2 \\
\hline Szwecja & 245,6 & 357,4 & 453,0 & 478,6 & 403,6 \\
\hline Węgry & 48,0 & 110,4 & 138,4 & 154,2 & 128,8 \\
\hline Wielka Brytania & 1477,5 & 2226,3 & 2803,4 & 2662,7 & 2173,2 \\
\hline Włochy & 1097,3 & 1762,5 & 2101,6 & 2303,1 & 2112,8 \\
\hline
\end{tabular}

Źródło: Opracowano na podstawie: Mały Rocznik Statystyczny Polski 2007, GUS, Warszawa 2007, s. 591-592; Maty Rocznik Statystyczny Polski 2009, GUS, Warszawa 2009, s. 592-593; Mały Rocznik Statystyczny Polski 2010, GUS, Warszawa 2010, s. 602-603; Mały Rocznik Statystyczny Polski 2011, GUS, Warszawa 2011, s. 605-606.

W 2008 r. w porównaniu do 2007 r. nastapił spadek produktu krajowego brutto w jednym $\mathrm{z}$ analizowanych państw, tj. w Wielkiej Brytanii - o 5,0\%. W pozostałych państwach miał miejsce jeszcze wzrost produktu krajowego brutto - od 2,1\% w Irlandii do aż 26,4\% na Słowacji. Niestety w kolejnym roku, w porównaniu do poprzedniego, we wszystkich zestawionych państwach nastąpił spadek produktu krajowego brutto - od 6,7\% w Belgii do aż 18,6\% w Polsce, czy 18,4\% w Wielkiej Brytanii (wykres 1). Oznaczało to jednoznacznie załamanie wzrostu gospodarczego, tym samym traktowanego na równi z początkiem kryzysu w gospodarce europejskiej.

Wykres 1. Dynamika produktu krajowego brutto w państwach UE w latach 2007-2009 (ceny bieżące, w mld USD, wg kursów walut)

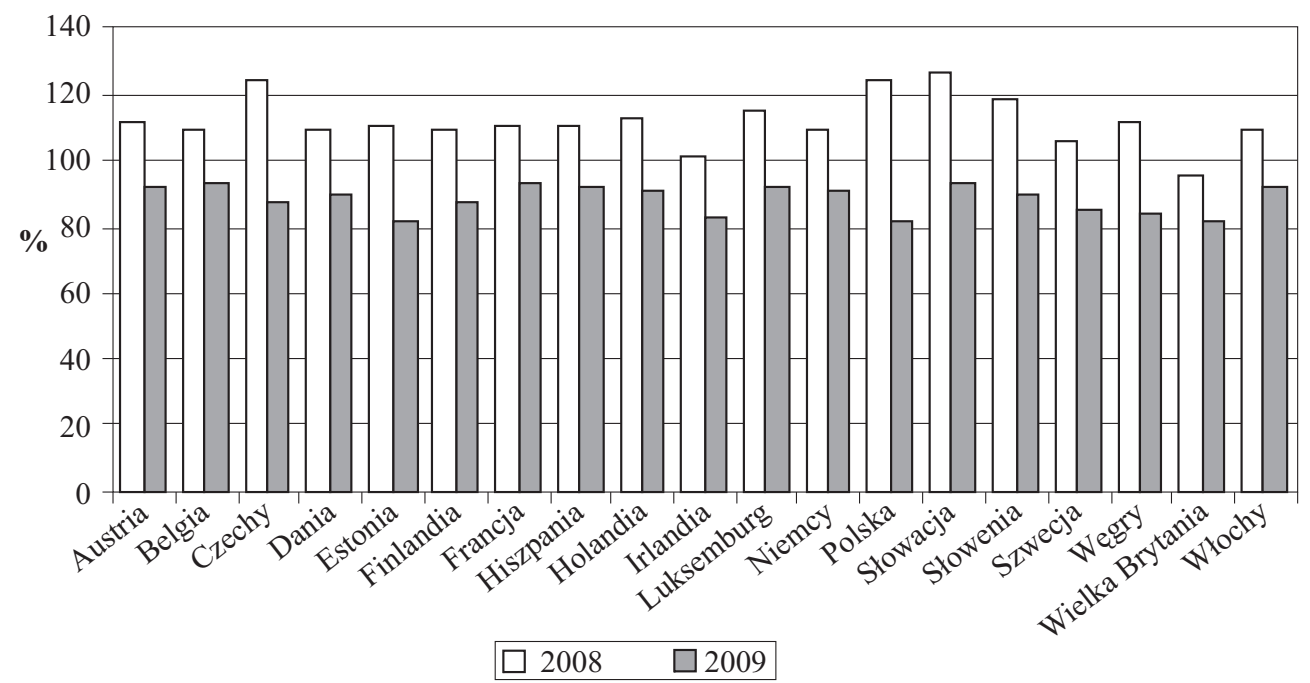

Uwaga: Wskaźniki dynamiki:

2008 r.: 2007 r. $=100 \%$

2009 r.: 2008 r. $=100 \%$

Źródło: Opracowanie własne.

W rozpatrywanej grupie państw UE, w latach 2000-2009 wystąpił wzrost produktu krajowego brutto per capita. Dynamika jego wzrostu nie była równa. W przedziale 2000-2005 z reguły była wyższa niż w przedziale 2005-2009 (tabela 2). 
Produkt krajowy brutto na 1 mieszkańca w państwach UE w latach 2000-2009

\begin{tabular}{|c|c|c|c|c|c|}
\hline \multirow{4}{*}{ Państwo } & \multicolumn{5}{|c|}{ PKB (ceny bieżące) na 1 mieszkańca wg parytetu sily nabywczej } \\
\hline & \multicolumn{5}{|c|}{ lata } \\
\hline & 2000 & 2005 & 2007 & 2008 & 2009 \\
\hline & USD & USD & USD & USD & USD \\
\hline Austria & 28736 & 34393 & 37119 & 37858 & 38823 \\
\hline Belgia & 27540 & 32998 & 35382 & 35288 & 36308 \\
\hline Czechy & 14975 & 20606 & 24027 & 24631 & 25530 \\
\hline Dania & 28789 & 34137 & 35961 & 36808 & 37688 \\
\hline Estonia & 9894 & 14926 & 20584 & 20648 & 19880 \\
\hline Finlandia & 25653 & 30959 & 34718 & 35809 & 35237 \\
\hline Francja & 25232 & 30266 & 32686 & 33090 & 33698 \\
\hline Hiszpania & 21295 & 27400 & 31586 & 31455 & 32254 \\
\hline Holandia & 29371 & 35120 & 39225 & 41063 & 40813 \\
\hline Irlandia & 28648 & 38850 & 45027 & 41493 & 39571 \\
\hline Luksemburg & 53315 & 70245 & 79793 & 84713 & 84803 \\
\hline Niemcy & 25919 & 30777 & 34391 & 35432 & 36340 \\
\hline Polska & 10555 & 13894 & 15854 & 17294 & 18929 \\
\hline Słowacja & 10962 & 15983 & 20079 & 22141 & 22871 \\
\hline Słowenia & 17603 & $20537^{\mathrm{a}}$ & 27227 & 27865 & 27536 \\
\hline Szwecja & 27726 & 32111 & 36603 & 36790 & 36996 \\
\hline Węgry & 12268 & 17483 & 18754 & 19732 & 20280 \\
\hline Wielka Brytania & 26041 & 32860 & 35669 & 35639 & 35159 \\
\hline Włochy & 25565 & 28094 & 30381 & 31253 & 32408 \\
\hline
\end{tabular}

a $-2004 \mathrm{r}$.

Źródło: Opracowano na podstawie: Maly Rocznik Statystyczny Polski 2007, GUS, Warszawa 2007, s. 591-592; Maty Rocznik Statystyczny Polski 2009, GUS, Warszawa 2009, s. 592-593; Mały Rocznik Statystyczny Polski 2010, GUS, Warszawa 2010, s. 602-603; Maty Rocznik Statystyczny Polski 2011, GUS, Warszawa 2011, s. $605-606$.

Jednak analizując wskaźniki produktu krajowego brutto per capita w następnych latach można zauważyć, że są one silnie zróżnicowane. Widoczne dysonanse odzwierciedlają choćby różnice w poziomie rozwoju gospodarczego państw oraz dobrobytu ich mieszkańców. W porównaniu do roku poprzedniego, w 2008 r. nastąpił spadek produktu krajowego brutto per capita w 4 państwach: Belgii, Hiszpanii, Irlandii, Wielkiej Brytanii, a w 2009 r. - w 6 państwach: Estonii, Finlandii, Holandii, Irlandii, Słowenii, Wielkiej Brytanii (wykres 2).

W latach 2000-2009 wydatki na ochronę zdrowia w rozpatrywanych państwach UE, obliczone w procentach produktu krajowego brutto sukcesywnie się podnosiły (tabela 3). W latach 2005-2007, wydatki te wzrosły w 6 państwach, zmalały w 12, a w jednym utrzymywały się na tym samym poziomie. Uwzględniając w tym okresie wzrost produktu krajowego brutto w 19 rozpatrywanych państwach, niższy wskaźnik procentowy wydatków na ochronę zdrowia nie musiał od razu oznaczać obniżenia ich wartości bezwzględnej. 
Wykres 2. Dynamika produktu krajowego brutto w państwach UE w latach 2007-2009 (ceny bieżące, na 1 mieszkańca w USD, wg parytetu sily nabywczej)

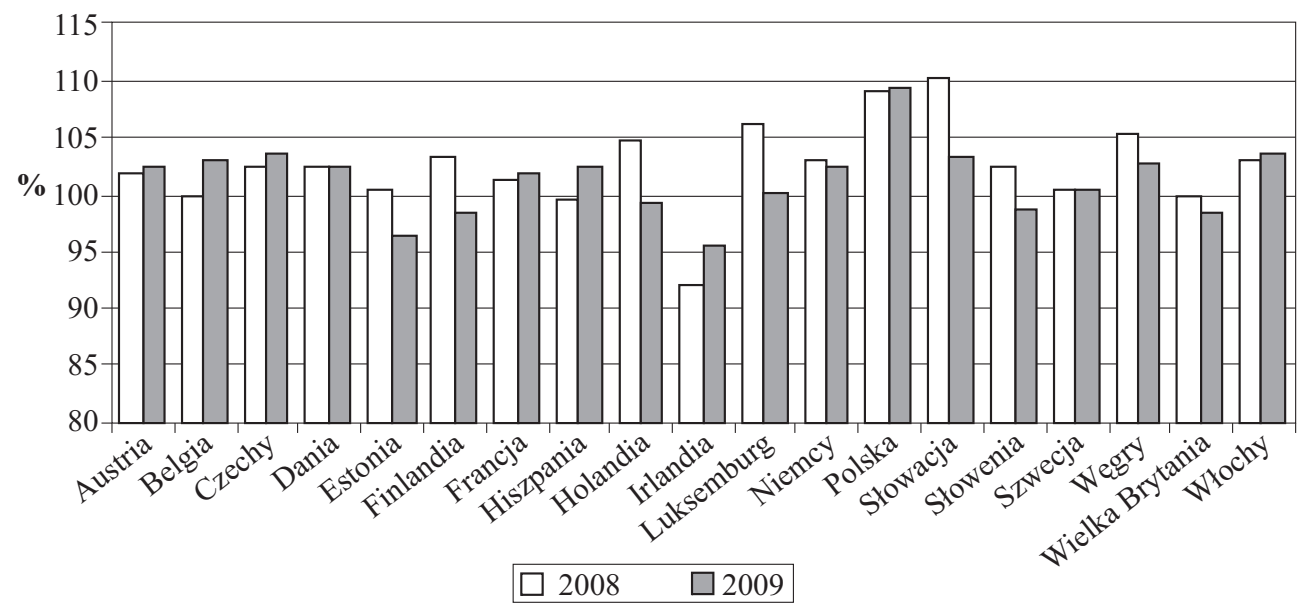

Uwaga: Wskaźniki dynamiki: 2008 r.: 2007 r. =100\%; 2009 r.: 2008 r. $=100 \%$.

Źródło: Opracowanie własne.

Tabela 3

Wydatki na ochronę zdrowia ogółem w procentach produktu krajowego brutto w państwach UE w latach 2000-2009

\begin{tabular}{|c|c|c|c|c|c|}
\hline \multirow{4}{*}{ Państwo } & \multicolumn{5}{|c|}{ Wydatki na ochronę zdrowia } \\
\hline & \multicolumn{5}{|c|}{ lata } \\
\hline & 2000 & 2005 & 2007 & 2008 & 2009 \\
\hline & $\%$ PKB & $\%$ PKB & $\%$ PKB & $\%$ PKB & $\%$ PKB \\
\hline Austria & 9,9 & 10,4 & 10,3 & 10,4 & 11,0 \\
\hline Belgia & 9,0 & 10,1 & 10,8 & 10,1 & 10,9 \\
\hline Czechy & 6,5 & 7,2 & 6,8 & 7,1 & 8,2 \\
\hline Dania & 8,3 & 9,8 & 9,7 & 10,3 & 11,5 \\
\hline Estonia & 5,3 & 5,0 & 5,3 & 6,1 & 7,0 \\
\hline Finlandia & 7,2 & 8,4 & 8,2 & 8,4 & 9,2 \\
\hline Francja & 10,1 & 11,1 & 11,0 & 11,1 & 11,8 \\
\hline Hiszpania & 7,2 & 8,3 & 8,4 & 9,0 & 9,5 \\
\hline Holandia & 8,0 & 9,8 & 9,7 & 9,9 & 12,0 \\
\hline Irlandia & 6,1 & 7,6 & 7,5 & 8,8 & 9,5 \\
\hline Luksemburg & 7,5 & 7,9 & 7,1 & 6,8 & 7,8 \\
\hline Niemcy & 10,3 & 10,7 & 10,4 & 10,7 & 11,6 \\
\hline Polska & 5,5 & 6,2 & 6,4 & 7,0 & 7,4 \\
\hline Słowacja & 5,5 & 7,0 & 7,7 & 8,0 & 9,1 \\
\hline Słowenia & 8,3 & 8,4 & 7,8 & 8,4 & 9,3 \\
\hline Szwecja & 8,2 & 9,1 & 9,1 & 9,2 & 10,0 \\
\hline Węgry & 7,0 & 8,3 & 7,4 & 7,2 & 7,4 \\
\hline Wielka Brytania & 7,0 & 8,2 & 8,4 & 8,8 & 9,8 \\
\hline Włochy & 8,1 & 8,9 & 8,7 & 9,0 & 9,5 \\
\hline
\end{tabular}

Źródło: Opracowano na podstawie: Podstawowe dane z zakresu ochrony zdrowia w 2009 r., GUS, Warszawa 2010, s. 217; Zdrowie i ochrona zdrowia w 2010 r., GUS, Warszawa 2012, s. 289. 
W porównaniu do roku poprzedniego w 2008 r. nastąpiło obniżenie wydatków na opiekę zdrowotną w relacji procentowej do produktu krajowego brutto tylko w 3 państwach: Belgii, Luksemburgu, na Węgrzech, a w 2009 r. - we wszystkich państwach nastąpił wzrost, nawet o ponad $20 \%$ (wykres 3 ).

Wydatki na ochronę zdrowia w USD w przeliczeniu na jednego mieszkańca w rozpatrywanych państwach UE są silnie zróżnicowane (tabela 4). W państwach wysoko rozwiniętych „starej” Unii są kilkakrotnie wyższe niż w państwach - nowych członkach UE. Biorąc pod uwagę, że nowoczesne, wysoko zaawansowane technologicznie i technicznie procedury medyczne są kosztowne, powoduje to, że dostępność do tych świadczeń w państwach o niskich wydatkach na opiekę zdrowotną jest nie tylko zawężona, ale i wydłużona w czasie.

Wykres 3. Dynamika wydatków na ochronę zdrowia ogółem w procentach produktu krajowego brutto w państwach UE w latach 2007-2009

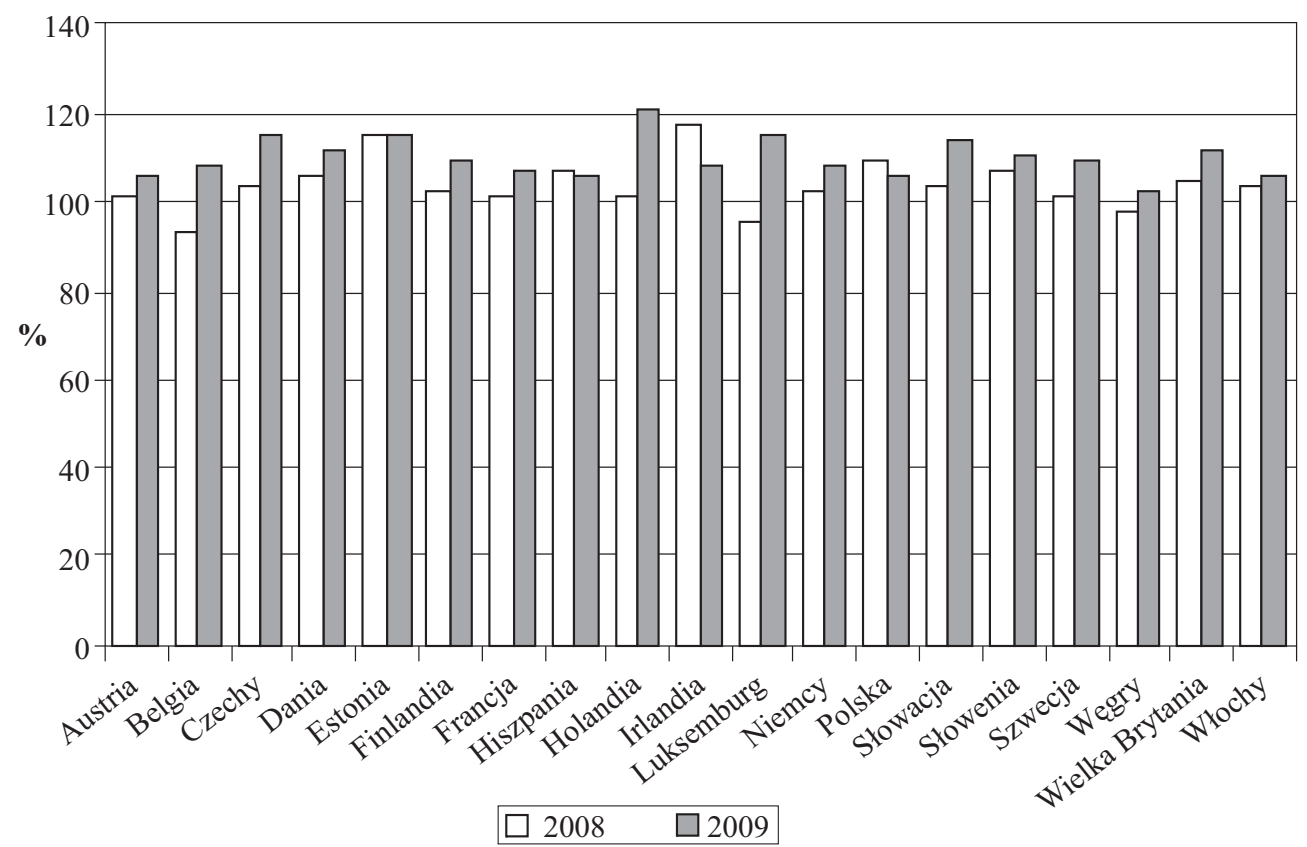

Uwaga: Wskaźniki dynamiki: 2008 r.: 2007 r. = 100\%; 2009 r.: 2008 r. = 100\%.

Źródło: Opracowanie własne.

W rozpatrywanym okresie we wszystkich analizowanych państwach nastapił wzrost wydatków na ochronę zdrowia w przeliczeniu na jednego mieszkańca. Jednak rozpatrując przedział lat 2005-2007 należy stwierdzić, że w 18 państwach nastąpiło zwiększenie tychże wydatków, a w jednym państwie - na Węgrzech miało miejsce ich obniżenie, co było zjawiskiem niekorzystnym, z punktu widzenia zapewnienia bezpieczeństwa zdrowia.

W porównaniu do roku poprzedniego w 2008 r. nastąpiło zmniejszenie (o 0,6\%) wydatków przeliczonych w USD na jednego mieszkańca tylko w Belgii. W pozostałych państwach, ten wzrost kształtował się w przedziale od 1,5\% (Luksemburg) do 21,7\% (Estonia). W 2009 r. w porównaniu do roku poprzedniego również miało miejsce zmniejszenie wydatków jednostkowych w jednym państwie - w Irlandii tylko o 0,1\% (wykres 4). 
Wydatki na ochronę zdrowia ogółem na 1 mieszkańca w państwach UE w latach 2000-2009

\begin{tabular}{|c|c|c|c|c|c|}
\hline \multirow{4}{*}{ Państwo } & \multicolumn{5}{|c|}{ Wydatki na ochronę zdrowia na 1 mieszk. wg parytetu sily nabywczej } \\
\hline & \multicolumn{5}{|c|}{ lata } \\
\hline & 2000 & 2005 & 2007 & 2008 & 2009 \\
\hline & USD & USD & USD & USD & USD \\
\hline Austria & 2862 & 3472 & 3792 & 4128 & 4289 \\
\hline Belgia & 2481 & 3231 & 3735 & 3714 & 3946 \\
\hline Czechy & 982 & 1475 & 1621 & 1839 & 2108 \\
\hline Dania & 2383 & 3245 & 3540 & 4052 & 4348 \\
\hline Estonia & 522 & 831 & 1094 & 1331 & 1393 \\
\hline Finlandia & 1855 & 2589 & 2900 & 3158 & 3226 \\
\hline Francja & 2553 & 3306 & 3593 & 3809 & 3978 \\
\hline Hiszpania & 1538 & 2269 & 2658 & 2971 & 3067 \\
\hline Holandia & 2340 & 3450 & 3853 & 4241 & 4914 \\
\hline Irlandia & 1763 & 2959 & 3361 & 3784 & 3781 \\
\hline Luksemburg & 3269 & 4152 & 4386 & 4451 & 4808 \\
\hline Niemcy & 2669 & 3364 & 3619 & 3963 & 4218 \\
\hline Polska & 583 & 857 & 1049 & 1265 & 1394 \\
\hline Słowacja & 604 & 1139 & 1569 & 1859 & 2084 \\
\hline Słowenia & 1453 & 1974 & 2077 & 2451 & 2579 \\
\hline Szwecja & 2286 & 2963 & 3349 & 3644 & 3722 \\
\hline Węgry & 853 & 1411 & 1395 & 1495 & 1511 \\
\hline Wielka Brytania & 1837 & 2735 & 2990 & 3281 & 3487 \\
\hline Włochy & 2064 & 2516 & 2701 & 3059 & 3137 \\
\hline
\end{tabular}

Źródło: Opracowano na podstawie: Podstawowe dane z zakresu ochrony zdrowia..., op. cit., s. 217; Zdrowie i ochrona zdrowia..., op. cit., s. 289.

Wykres 4. Dynamika wydatków na ochronę zdrowia ogółem w państwach UE w latach 2007-2009 (na 1 mieszkańca w USD, wg parytetu sily nabywczej)

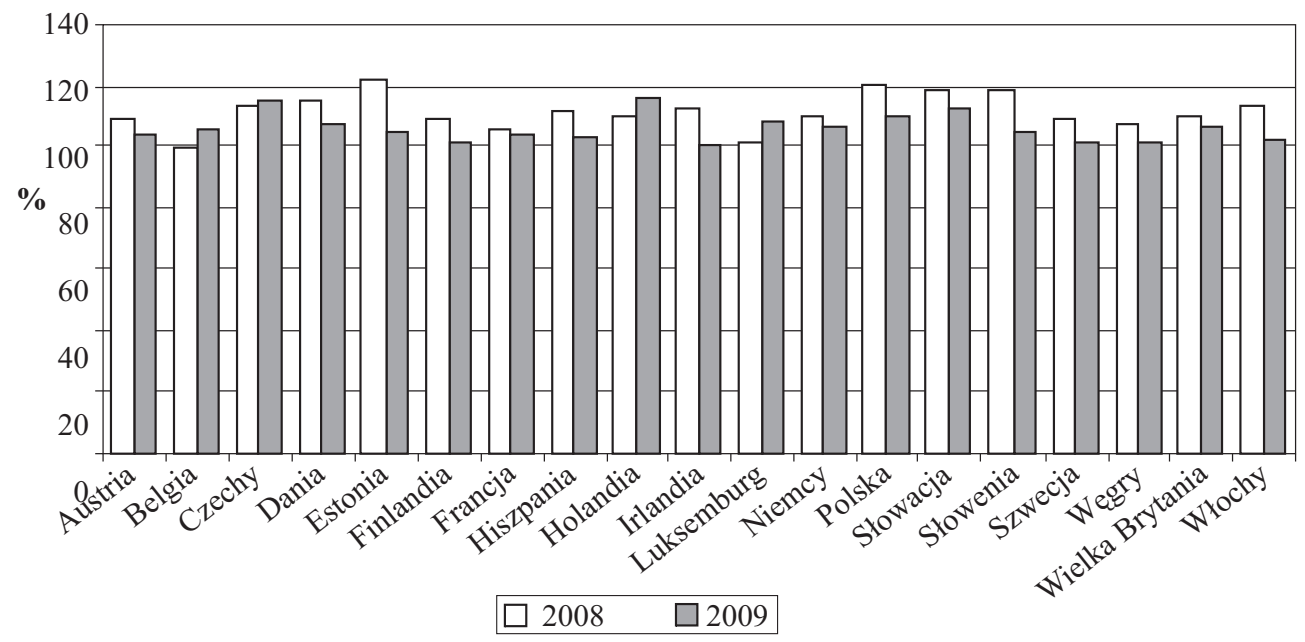

Uwaga: Wskaźniki dynamiki: 2008 r.: 207 r. = 100\%; 2009 r.: 2008 r. =100\%.

Źródło: Opracowanie własne. 
Wskaźniki dynamiki, jeśli nawet były znacząco wyższe w państwach nowo przyjętych do UE, niż w państwach ,starej” Unii, nie oznaczają dla ich społeczeństw przełomu w finansowaniu sytemu ochrony zdrowia, z uwagi na niską bezwzględną wielkość tychże wydatków. Dynamika wydatków na ochronę zdrowia w 2009 r. w porównaniu do 2008 r. uległa osłabieniu w 15 państwach, a tylko w 4 okazała się silniejsza. Biorąc pod uwagę, że w rozpatrywanych państwach wystąpiło zmniejszenie produktu krajowego brutto, tendencja zwiększenia wydatków na ochronę zdrowia jest korzystna dla rozpatrywanych populacji.

\section{Wnioski}

W wyniku analizy danych statystycznych charakteryzujących sytuację makroekonomiczną oraz finansowanie ochrony zdrowia w badanych państwach UE do 2009 r. można stwierdzić, że załamanie wzrostu gospodarczego:

1) nie wpłynęło na obniżenie wielkości wydatków na ochronę zdrowia,

2) doprowadziło do osłabienia dynamiki wydatków na ochronę zdrowia,

3) nie wywołało zmian w zróżnicowaniu wydatków na ochronę zdrowia.

Reasumując: kryzys gospodarczy w analizowanej fazie nie wpłynął na obniżenie bezpieczeństwa zdrowia publicznego $\mathrm{w}$ rozpatrywanych państwach UE.

\section{Bibliografia}

Białynicki P., Wplyw zdrowia na ksztaltowanie się spolecznego dobrobytu, „Biuletyn Ekonomiczny GAP” 2007, $\mathrm{nr} 3$, http://www.biuletyn.e-gap.pl/index.php?view=artykul\&artykul=43.

Kissimova-Skarbek K., Finansowanie opieki zdrowotnej, w: Zdrowie publiczne. Wybrane zagadnienia, t. II, red. A. Czupryna, S. Poździoch, A. Ryś, W. C. Włodarczyk, Uniwersyteckie Wydawnictwo Medyczne,,Vesalius", Kraków 2001.

Mały Rocznik Statystyczny Polski 2007, 2009, 2010, 2011, GUS, Zakład Wydawnictw Statystycznych, Warszawa 2007, 2009, 2010, 2011.

Morawski W., Kronika kryzysów gospodarczych, Wydawnictwo TRIO, Warszawa 2003.

Nawrot W., Globalny kryzys finansowy XXI wieku. Przyczyny, przebieg, skutki, prognozy, Wydawnictwo CeDeWu Sp. z o.o., Warszawa 2009.

Podstawowe dane z zakresu ochrony zdrowia w 2009 r., GUS, Zakład Wydawnictw Statystycznych, Warszawa 2010.

Podstawy zarzadzania zakładem opieki zdrowotnej, red. M. Dobska, K. Rogoziński, Wydawnictwo Naukowe PWN, Warszawa 2008.

Przestanie Dyrektora Generalnego, http://pck.org.pl/images/news_obraz/2007_sdz/Przeslanie_DG_WHO.pdf.

Stanowisko Rzqdowej Rady Ludnościowej w sprawie „Bezpieczeństwo zdrowotne ludności Polski”, http://www.stat.gov.pl/cps/rde/xbcr/bip/BIP_stanowisko_RRL_bezp_zdrow_ludnosci.pdf.

Szpak J., Historia gospodarcza powszechna, Polskie Wydawnictwo Ekonomiczne, Warszawa 2007.

Światowy Dzień Zdrowia 2007, http://kobieta.wp.pl/kat,26377,title,Swiatowy-Dzien-Zdrowia-2007,wid,8810278, wiadomosc.html?ticaid=1e46d.

Światowy Dzień Zdrowia 2007, Uniwersyteckie Centrum Kliniczne, https:/www.uck.gda.pl/content/ view/983/90/.

Włodarczyk C., Poździoch S., Pojęcie i zakres zdrowia publicznego, w: Zdrowie publiczne. Wybrane zagadnienia, t. I, red. A. Czupryna, S. Poździoch, A. Ryś, W. C. Włodarczyk, Uniwersyteckie Wydawnictwo Medyczne „Vesalius”, Kraków 2000.

Zdrowie i ochrona zdrowia w 2010 r., GUS, Zakład Wydawnictw Statystycznych, Warszawa 2012. 
The influence of the economic crisis on the security of public health in the EU

\section{Summary}

The paper emphasizes the significance of health for individual existence and the entire population. It indicates the fundamental elements of health security in the EU. It presents the reasons for and results of economic crisis. The interdependencies between the economic situation and a society's health are defined. Statistical data provide the basis for the analysis and assessment of the influence the present economic crisis has had on the security of public health in the EU. 
